\title{
Psychometric-based domestic violence instruments as an assessment in experiential family counseling
}

\author{
Rima Pratiwi Fadli*), A. Muri Yusuf, Firman Firman \\ Department of Guidance and Counseling, Universitas Negeri Padang, Indonesia
}

\begin{tabular}{l} 
Article Info \\
\hline Article history: \\
Received Oct $08^{\text {th }}, 2021$ \\
Revised Nov $04^{\text {th }}, 2022$ \\
Accepted Des $28^{\text {th }}, 2022$ \\
\hline
\end{tabular}

\section{Keyword:}

Domestic violance

Psychometric

Assesment in counseling

Experiential family counseling

Measurement of psychology

\begin{abstract}
Domestic abuse is a topic that is often discussed in the community. Experiential family counseling can be used to deal with domestic abuse. In terms of handling, it is vital to undertake a customer assessment. Standard domestic violence instruments that can be utilized in experiential family counseling have not been discovered as a result of library study. As a result, psychometric-based domestic violence tools are required. The creation of psychometric-based instruments results in instruments with high validity and reliability, such as test kits. The Delphi method, focus group discussion, factor analysis, and analysis of standard error of measurement were all used. According to the findings of the study, the application of this psychometricbased instrument has strong discriminating validity and no cross-loading, indicating good convergent validity. In terms of dependability, it also develops devices with a high level of dependability. So that psychometric analysis for evaluation in experiential family therapy can be used to build this instrument of domestic violence.
\end{abstract}

(C) 2022 The Authors. Published by IICET.

This is an open access article under the CC BY-NC-SA license

(https://creativecommons.org/licenses/by-nc-sa/4.0

\section{Corresponding Author:}

Rima Pratiwi Fadli,

Universitas Negeri Padang

Email: rimapratiwifadly@gmail.com

\section{Introduction}

The family as a system serves as a foundation for implementing family treatments such as therapy or counseling (Saputri, 2020). The family can also be viewed as a social institution with the principle of being the primary determinant of the community member's type (Basir, 2020). The home is also the first location for children to receive an education (Mintarsih, 2013) both physically, psychologically, and spiritually (Basir, 2020). If the family function is successful, it can result in a sakinah, joyful, and physically and psychologically healthy family (Handayani et al., 2018).

In terms of the family's role as a place where people protect one another, give affection, and promote psychological well-being (Fadli, 2019). In the meantime, the reality on the ground is that the family function is broken. This situation makes the family an unsafe and dangerous place to be in, as well as causing psychological problems for its members (Kadir \& Handayaningsih, 2020; Kartono, 2005). The presence of violence against women, particularly violence against women in the home, is a common occurrence in the field.

The act of violence against women is classified as a violation of the law and human rights (Fitriah, 2021; Triwahyuningsih, 2018). This has now become a common occurrence in people's life. The Indonesian people 
and the international society have paid attention to violence against women (Dewi, 2014). This is due to the fact that violence against women is a global phenomena that cannot be eradicated; in fact, it is on the rise.

Divorce is one of the factors that causes domestic violence (Ratnawaty, 2014). This situation is backed up by the fact that Indonesia's divorce rate is rising every year (Hidayati, 2021; Ratnawaty, 2014). Domestic violence cases reached 8,764 in 2018, making it the fourth most common (Hidayati, 2021). Domestic violence against women is on the rise, indicating that the home is no more a safe and pleasant environment for women (Hitijahubessy et al., 2018). The victim's psychological status was influenced by a variety of negative experiences (Ariyanti \& Ardhana, 2020; Maysitoh \& Fitriani, 2017; Rahmawati, 2014; Ramadhon \& Gorda, 2020). Changes in psychological circumstances are experienced by victims, such as the victim becoming grumpy, preferring to be alone, not believing in a brighter future, and being uninterested in living life (Ellsberg et al., 2008).

The psychological care of domestic violence victims is unquestionably necessary. It creates the foundation for carrying out interventions in the form of therapy or counseling for families as a family system (Saputri, 2020). According to research, using family counseling can aid in optimal mediation outcomes, and many couples are able to reconcile (Vionita et al., 2020). Other data indicate that family counseling is useful in enhancing people's quality of life (Suryani \& Rahmawati, 2018). As a result, family counseling can be regarded as aiding in the maintenance of family harmony and the quality of family life. As a result, an experiential family counseling examination is required. This is because an assessment is required as part of this psychological treatment to determine the severity of domestic abuse experienced by the victim.

Psychometrics were used in the formulation of this domestic violence evaluation. To improve consistency, psychometric features are used in this examination. The developed instrument was subjected to factor analysis. The instrument produced is expected to aid counselors or therapists in researching the requirements of victims of domestic violence. An instrument based on psychometric features will be developed as part of this project.

\section{Method}

This paper was written with the help of a library research method. We examined various articles from national and international journals while preparing this essay. The publications under consideration are those that discuss domestic violence instruments that were developed using psychometry. The procedure of selecting publications relevant to the development of psychometric-based household violance devices yielded the related articles. After that, the selected scientific articles are reviewed and analyzed for each advancement. After that, the writers drew conclusions from each of the study articles' descriptions of the development of domestic violence instruments.

\section{Results and Discussions}

\section{Family}

As one of society's social institutions, the family plays an important role in establishing behavioral patterns and internalizing normative norms (Syarbini, 2014). According to Islam, the existence of a family proves that a servant obeys Allah SWT's commands and follows the Prophet Muhammad's sunnah (Wahidin, 2017). Openness, support, understanding, trust, and effective communication are required in a family (Novianti et al., 2017).

An ideal family can be rated based on its ability to accomplish its function in accordance with its role. However, as the times changed, so did the function of the family, resulting in family dysfunction and aberrations (Kurniawan, 2020). Meanwhile, the family should be the first block in the construction of a Muslim society by establishing a family as a faith madrasa (Al Hamat, 2018) capable of producing future generations of intelligent Muslims. As a result, it is critical to focus on restoring the family's role so that it can serve as a place to nurture behavior, achieve harmony, and provide a safe haven for its members.

\section{Domestic Violance}

Domestic violence is an attempt by both men and women to acquire control of a family's dominating position (Badriyah Khaleed, 2018). Discord in family relationships, economic troubles, and a lack of communication are all factors that contribute to the emergence of domestic violence (Setyaningrum \& Arifin, 2019). Domestic violence abusers attempt to gain control of the household through the use of rights, freedoms, and other means, such as prohibiting or forcing a wife to work (Setyaningrum \& Arifin, 2019).

Domestic abuse has an adverse effect on the victim's physical, psychological, and mental wellbeing (Setyaningrum \& Arifin, 2019). Domestic violence is defined as any act against a person, particularly a 
woman, that results in physical, sexual, psychological misery or suffering and/or neglect of the household, including threats to commit acts, coercion, or unlawful deprivation of liberty within the household, according to the domestic violence law (Aziz, 2017; Ernaningsih, 2014).

The family is a social organization made up of a mother, father, and children who share love, protect each other in order to attain happiness, and meet requirements through a legal link, namely marriage (Dedi, 2002; Syaiful, 2004). Family members engage and communicate with one another by respecting and appreciating one another.

If this is the case, the family's objectives will be met. As stated in Article 1 of the Marriage Law in general, the goal is to create a joyful and eternal family (home) based on the One Godhead (Walgito, 2004). In order to achieve this goal, the family's function must be maintained. Biological functions, economic functions, educational functions, socializing functions, protective functions, recreational functions, and religious functions are all ideal family roles (Syamsu, 2011).

Security and safety, as well as economic and material well-being, psychological, physical, and emotional well-being, and spiritual needs, are all functions of the family to meet the needs of its members (Kathryn \& David, 2011). The following are some of the issues that may occur as a result of inefficient family functions (Hasan, 2012; Willis, 2013): 1) The presence of communication issues, such as a lack of or break in contact between family members, particularly between dads and mothers, and a loss of communication openness. As a result, non-fluent communication might make it difficult for people to feel affection for one another; 2) The attitude of egocentrism, as well as the egocentrism of each husband and wife, is a source of home problems that lead to continual quarrels; 3) The existence of economic issues, which might be caused by poverty or a certain way of living. This disease can make you feel depressed and helpless; 4) The presence of busyness issues, which can lead to a bodily and psychological sense of discontent. There may be an affair, a loss of trust in one another, and for example, a loss of intimacy and love; 5) Educational issues: Educational issues are frequently the source of family crises. If both husband and wife have a good degree of education, they will be able to comprehend family life insights. Husbands and wives with a poor level of education, on the other hand, are frequently unable to comprehend the complexities of the family; 6) Lacking in religion, if a family lacks in faith and emphasizes the material and world, it might generate family rifts (Asmaya, 2012).

However, when family functions are disrupted, a lot can happen. For example, economic functions are disrupted, resulting in financial troubles for family members, and biological functions are disrupted, resulting in widespread issues of adultery in the family and other concerns. Domestic violence, according to the above viewpoint, includes all forms of physical and psychological abuse that inflict harm and have an influence on both the perpetrator and the victim.

\section{Experiential Family Counseling}

Each family member will have distinct impressions of other family members, which will influence their beliefs and attitudes, which will be influenced by the individual's personality qualities. Individuals who interact in a family will have an impact on the family as a whole through causing responses and behavioral patterns (Kathryn \& David, 2011).

Family conflicts are frequently caused by differences in personality features (Lestari, 2016). According to their individual perceptions, each family member has a different understanding, cognition, and action. Members of the family participate in activities that they believe best suit their needs. These requirements include emotional and physical requirements to alleviate worry and provide a sense of security. However, there are situations when what one family member does makes other family members uncomfortable or even uneasy. Family members may become enraged as a result of this. If the family members are unable to cope, they will require the assistance of a counselor.

The notion of experience family therapy was adapted into experiential family counseling. Counselors can utilize a variety of ways to aid a family in the therapy process. In its activity process, the counseling model connects a variety of family interactions. The fundamental premise of family therapy is that the family develops as a unit. Experiential family therapy is one of them.

This method emphasizes the significance of feeling and expressing emotions in the present moment. This style of therapy stresses the family's natural growth process, assisting family members in increasing their sense of belonging while also increasing the family's ability to grant each member individual freedom. Carl Whittaker, Virginia Satir, August Napier, David Keith, and Leslie Greenberg all made significant contributions to experiential family therapy. Existential, humanistic, and phenomenological are all terms used to describe experiential family therapy (Kathryn \& David, 2011). 
In terms of existentialists' belief that personal experiences might provide insight into human existence, Individual experience, as is well known, is the finest teacher. As a result, during the counseling process, counselors assist clients in determining which personal experiences may influence how they relate to emotions during treatment. Humanists believe that the therapeutic process necessitates faith in natural wisdom, dialogue, and truthful feelings. Humans have reason by nature, and allowing them to use it would make them more enthusiastic, creative, and productive (Mintarsih, 2013).

\section{Domestic Violence Instruments Based on Psychometric}

The science of psychological traits is known as psychometrics (Furr \& Bacharach, 2008). Psychometric features are those that have to do with the test's properties. The type of data or the score of the measurement findings, as well as the validity of the measurement data, are among the different features of the test. Validity refers to the ability of a measuring device to accurately measure or determine what is being measured or known (Yusuf, 2016). A test is deemed to be legitimate if it can accurately measure what each subject needs to know about certain talents. The domestic violance test is regarded to be valid if it accurately evaluates a person's level of domestic violance and can be used to compare various people with varying levels of domestic violance.

Validity is examined in reference to external criteria in this psychometric measurement to predict measurement accuracy. A test is considered really valid if it can correctly predict future behavior based on the variables created (validity criteria); 2) accurately measures the behavioral domain (content validity); and 3) accurately measures the test's properties (construct validity) (Setiawati, 2013). The concept of content validity was created to determine how well the attributes measured by an instrument correspond to the performance developed. Experts conduct rational analysis, which is referred to as professional judgment, to determine content validity. With the Delphi technique, content validity examination can be done quantitatively and qualitatively through focus group discussion activities (Listyanawati, 2015; Musianto, 2002; Sugiyanto et al., 2015).

The construct validity of a test indicates that it discloses a theoretical construct that it measures or a trait developed during the instrument's development (Mardapi, 2008). Construct is a fundamental principle that underpins all instruments. Experts recommend factor analysis and multimethod testing to assess construct validity (Yusrizal, 2017). Factor analysis is a technique for minimizing the number of variables or dimensions needed to simplify or summarize data (Donawati, 2014). Factor analysis is a technique for simplifying many measurements and tests. Exploratory and confirmatory factor analysis is the method employed (Setiawati, 2011).

Furthermore, the criteria's validity assesses a test's capacity to predict performance on other tests (Suharman, 2018). The correlation between the test scores and the corresponding criteria scores is used to calculate criterion validity (Arif, 2017). The stronger the correlation, the better the correlation between the test scores and the expected criteria, demonstrating the measuring instrument's accuracy in assessing specific characteristics. Meanwhile, if the test being measured is used to predict future behavior or performance, predictive validity is critical.

In terms of the measurement data's reliability, measurement mistakes are a concern. The score variance can be used to explain the measurement data's reliability. The standard error of measurement is the word for error variation (SEM). The size of the SEM has an impact on reliability, therefore the accuracy of the measurement findings can be determined by the size of the SEM. The more exact, reliable, and repeatable the SEM measurement, the more accurate, repeatable, and repeatable the measurement results will be (Setiawati et al., 2013).

A parallel test strategy is used to determine reliability by taking measurements using two parallel test sets, for example, the first and second sets are presented to a group of subjects (Alwi, 2015). The correlation between the scores of the first and second devices was used to compute the reliability coefficient. In addition, in the internal consistency technique, measurements are given to a group of participants only once, and then the test reliability coefficient is calculated in a certain fashion (Arifin, 2017).

Using research data and psychometric features, a viable tool for identifying teenage mental health disorders can be developed (Glozah \& Pevalin, 2015). There are numerous dimensions measured in this study, according to the development of an instrument to measure psychological and sexual intimate partner violence (IPV) (Yakubovich et al., 2019). This psychometric analysis uses a polychoric (not Pearson) correlation matrix, which takes into account variables that are ordinal rather than continuous, to pay attention to numerous points in instrument creation (Yakubovich et al., 2019). This means that the instrument built can be utilized in future studies. 
The instrument's psychometric features were also used to create an inventory of beliefs and attitudes about domestic abuse. Exploratory factor analysis was used to find five components with a Cronbach's alpha of 0.646. The loading factor for this development is greater than 0.80 , indicating that the instrument has strong discriminating validity. Cross-loading is not present, indicating strong convergent validity (Hutchinson \& Doran, 2017).

\section{Conclusions}

Domestic violence is becoming more prevalent in the community as time goes on. Especially during the COVID-19 pandemic, there are a lot of cases. Experiential family counseling can be used to help victims of domestic violence deal with their psychological problems. It is required to do an assessment prior to implementation. Existing tests lack specific requirements, necessitating the creation of a psychometrically based standard domestic violance instrument. This tool is intended to assist counselors and therapists in dealing with clients who have been victims of domestic violence.

\section{References}

Al Hamat, A. (2018). Representasi Keluarga dalam Konteks Hukum Islam. YUDISIA: Jurnal Pemikiran Hukum dan Hukum Islam, 8(1), 139-154.

Alwi, I. (2015). Kriteria empirik dalam menentukan ukuran sampel pada pengujian hipotesis statistika dan analisis butir. Formatif: Jurnal Ilmiah Pendidikan MIPA, 2(2).

Arif, W. P. (2017). Pengembangan Tes Kognitif pada Materi Sistem Pernapasan. Jurnal Biotek, 5(2), $108-122$.

Arifin, Z. (2017). Kriteria instrumen dalam suatu penelitian. Jurnal THEOREMS (The Original Research of Mathematics), 2(1), 28-36.

Ariyanti, N. M. P., \& Ardhana, I. K. (2020). Dampak Psikologis dari Kekerasan dalam Rumah Tangga terhadap Perempuan pada Budaya Patriarki di Bali. Jurnal Kajian Bali (Journal of Bali Studies), 10(1), 283304-283-304.

Asmaya, E. (2012). Implementasi agama dalam mewujudkan keluarga sakinah. Komunika: Jurnal Dakwah dan Komunikasi, 6(1).

Aziz, A. (2017). Islam Dan Kekerasan Dalam Rumah Tangga. Kordinat: Jurnal Komunikasi antar Perguruan Tinggi Agama Islam, 16(1), 177-196.

Badriyah Khaleed, S. (2018). Penyelesaian Hukum KDRT: Penghapusan Kekerasan dalam Rumah Tangga dan Upaya Pemulihannya. Media Pressindo.

Basir, S. (2020). Membangun Keluarga Sakinah. Al-Irsyad Al-Nafs: Jurnal Bimbingan dan Penyuluhan Islam, 6(2).

Dedi, J. (2002). Bimbingan Perkawinan (Membina Keluarga Sakinah Menurut Al Qur'an Dan As Sunnah). Akademika Pressindo.

Dewi, M. A. (2014). Media Massa dan Penyebaran Isu Perempuan. Jurnal Ilmu Komunikasi, 7(3), 228-236.

Donawati, D. (2014). Pengaruh Kualitas Jasa Terhadap Kepuasan Nasabah Perbankan Syari'ah Di Pekanbaru. Jurnal Ilmiah Ekonomi dan Bisnis Unilak, 11(2), 98346.

Ellsberg, M., Jansen, H. A., Heise, L., Watts, C. H., \& Garcia-Moreno, C. (2008). Intimate partner violence and women's physical and mental health in the WHO multi-country study on women's health and domestic violence: an observational study. The lancet, 371(9619), 1165-1172.

Ernaningsih, W. (2014). Perspektif Gender dalam Undang-Undang Kekerasan dalam Rumah Tangga. Jurnal Ilmiah Pusat Studi Wanita Jipswari, 1(1).

Fadli, R. P. (2019). Kontribusi Dukungan Sosial Teman Sebaya dan Tingkat Resiliensi terhadap Psychological WellBeing Remaja Korban Kekerasan dalam Rumah Tangga Universitas Negeri Padang]. Padang.

Fitriah, N. (2021). Kejahatan Kekerasan Psikis dan Penelantaran Perempuan sebagai Pelanggaran Hak Asasi Manusia. DE JURE Critical Laws Journal, 2(1), 23-35.

Furr, M., \& Bacharach, V. (2008). Psychometrics: an introduction. . Sage Publications.

Glozah, F. N., \& Pevalin, D. J. (2015). Factor structure and psychometric properties of the General Health Questionnaire (GHQ-12) among Ghanaian adolescents. Journal of Child \& Adolescent Mental Health, 27(1), 53-57.

Handayani, A., Yulianti, P. D., \& Ardini, S. N. (2018). Membina Keluarga Sejahtera Melalui Penerapan 8 Fungsi Keluarga. J-ABDIPAMAS (Jurnal Pengabdian Kepada Masyarakat), 2(1), 76-80.

Hasan, M. (2012). Bahan Ajar Bimbingan dan Konseling. BK FIP UNP.

Hidayati, L. (2021). Fenomena Tingginya Angka Perceraian Di Indonesia Antara Pandemi dan Solusi. Khuluqiyya, 3(1), 71-87. 
Hitijahubessy, C. N., Affiyanti, Y., \& Budiati, T. (2018). Dukungan sosial dan kualitas hidup fisik perempuan korban kekerasan dalam rumah tangga. Jurnal Kesehatan Terpadu (Integrated Health Journal), 9(1), 1-10.

Hutchinson, M., \& Doran, F. (2017). Psychometric testing of inventory of beliefs and attitudes on domestic violence. Nurse researcher, $25(1)$.

Kadir, A., \& Handayaningsih, A. (2020). Kekerasan Anak dalam Keluarga. Wacana, 12(2), 133-145.

Kartono, M. (2005). Perbandingan perilaku agresif antara remaja yang berasal dari keluarga bercerai dengan keluarga utuh. Jurnal Psikologi Vol, 3(1), 1.

Kathryn, G., \& David, G. (2011). Konseling Keluarga. Pustaka Pelajar.

Kurniawan, F. (2020). Keluarga dan Budaya dalam Tinjauan Sosiologis (Vol. 3). G4 Publishing.

Lestari, S. (2016). Psikologi Keluarga: Penanaman Nilai dan Penanaman Konflik dalam Keluarga. Prenada Media.

Listyanawati, I. (2015). Peningkatkan kompetensi dalam penyusunan instrumen penilaian berbasis kurikulum 2013 melalui focus group discussion (FGD). Jurnal Rehabilitasi dan Remediasi, 24(2).

Mardapi, D. (2008). Teknik penyusunan instrumen tes dan nontes. Mitra Cendikia Press.

Maysitoh, M., \& Fitriani, D. (2017). Kebermaknaan Hidup Perempuan Korban KDRT: Konsep Psikologis dan Faktor yang Melatarbelakanginya. SCHOULID: Indonesian Journal of School Counseling, 2(3), 54-59.

Mintarsih, W. (2013). Peran Terapi Keluarga Eksperiensial Dalam Konseling Anak Untuk Mengelola Emosi. Sawwa: Jurnal Studi Gender, 8(2), 291-310.

Musianto, L. S. (2002). Perbedaan pendekatan kuantitatif dengan pendekatan kualitatif dalam metode penelitian. Jurnal Manajemen dan Kewirausahaan (Journal of Management and Entrepreneurship), 4(2), 123136.

Novianti, R. D., Sondakh, M., \& Rembang, M. (2017). Komunikasi antarpribadi dalam menciptakan harmonisasi (suami dan istri) keluarga didesa Sagea Kabupaten Halmahera Tengah. Acta Diurna Komunikasi, 6(2).

Rahmawati, M. (2014). Menulis ekspresif sebagai strategi mereduksi stres untuk anak-anak korban kekerasan dalam rumah tangga (KDRT). Jurnal Ilmiah Psikologi Terapan, 2(2), 276-293.

Ramadhon, S., \& Gorda, A. N. T. R. (2020). Perlindungan Hukum Terhadap Perempuan Sebagai Korban Kekerasan Dalam Rumah Tangga Secara Preventif Dan Represif. Jurnal Analisis Hukum, 3(2), 205-217.

Ratnawaty, L. (2014). Faktor Yuridis Sosiologis Meningkatnya Perceraian di Kota Bogor. YUSTISI, 1(2), 1522.

Saputri, J. (2020). jurnal_metode_penelitian. osf.io

Setiawati, F. A. (2011). Perbandingan penskalaan metode interval tampak setara (tipe thurstone) dan summated rating (tipe likert). Makalah Seminar Nasional. Fakultas Ilmu Pendidikan UNY,

Setiawati, F. A. (2013). Perbandingan Karakteristik Psikometrik Penskalaan Tipe Thurstone Paired Comparison dan Likert dengan Teori Klasik dan Modern: Studi pada Instrumen Multiple Intelligences Universitas Negeri Yogyakarta]. Yogyakarta.

Setiawati, F. A., Mardapi, D., \& Azwar, S. (2013). Penskalaan Teori Klasik Instrumen Multiple Intelligences Tipe Thurstone dan Likert. Jurnal Penelitian dan Evaluasi Pendidikan, 17(2), 261-274.

Setyaningrum, A., \& Arifin, R. (2019). Analisis Upaya Perlindungan dan Pemulihan Terhadap Korban Kekerasan dalam Rumah Tangga (KDRT) Khususnya Anak-Anak dan Perempuan. Jurnal Ilmiah Muqoddimah: Jurnal Ilmu Sosial, Politik dan Hummanioramaniora, 3(1), 9-19.

Sugiyanto, S., Kartowagiran, B., \& Jailani, J. (2015). Pengembangan Model Evaluasi Proses Pembelajaran Matematika Di SMP Berdasarkan Kurikulum 2013. Jurnal Penelitian dan Evaluasi Pendidikan, 19(1), 82-95.

Suharman, S. (2018). Tes Sebagai Alat ukur Prestasi Akademik. AT-TA'DIB: JURNAL ILMIAH PRODI PENDIDIKAN AGAMA ISLAM, 93-115.

Suryani, S., \& Rahmawati, R. (2018). Efektivitas konseling keluarga terhadap peningkatan kualitas hidup pasien hipertensi. The Shine Cahaya Dunia D-III Keperawatan, 3(1).

Syaiful, B. D. (2004). Pola Komunikasi Orang Tua \& Anak dalam Keluarga. Rineka Cipta.

Syamsu, Y. (2011). Psikologi perkembangan anak dan remaja. Remaja Rosdakarya.

Syarbini, A. (2014). Model Pendidikan Karakter Dalam Keluarga. Elex Media Komputindo.

Triwahyuningsih, S. (2018). Perlindungan dan Penegakan Hak Asasi Manusia (HAM) di Indonesia. Legal Standing: Jurnal Ilmu Hukum, 2(2), 113-121.

Vionita, V., Saefullah, C., \& Muttaqin, Z. (2020). Mediasi Perceraian melalui Konseling Keluarga Brimob Polda Jabar. Irsyad: Jurnal Bimbingan, Penyuluhan, Konseling, dan Psikoterapi Islam, 8(1), 77-96.

Wahidin, U. (2017). Peran strategis keluarga dalam pendidikan anak. Edukasi Islami: Jurnal Pendidikan Islam, $1(02)$.

Walgito, B. (2004). Bimbingan dan konseling perkawinan. Andi Offset.

Willis, S. (2013). Konseling Keluarga (Family Counseling) Suatu Upaya Anggota Keluarga Memecahkan Masalah Komunikasi didalam Sistem Keluarga. Alfabeta. 
Yakubovich, A. R., Heron, J., Feder, G., Fraser, A., \& Humphreys, D. K. (2019). Intimate partner violence victimisation in early adulthood: psychometric properties of a new measure and gender differences in the Avon Longitudinal Study of Parents and Children. BMJ Open, 9(3), e025621.

Yusrizal, Y. (2017). Pengembangan instrumen penilaian kinerja dosen di perguruan tinggi. PARAMETER: Jurnal Pendidikan Universitas Negeri Jakarta, 29(1), 108-120.

Yusuf, A. M. (2016). Metode penelitian kuantitatif, kualitatif \& penelitian gabungan. Prenada Media. 